\title{
PENGARUH SENAM JANTUNG SEHAT TERHADAP TEKANAN DARAH LANSIA DI PANTI TRESNA WERDHA HARGO DEDALI SURABAYA
}

\author{
Ethyca Sari $^{1}$ \\ ${ }^{1}$ STIKes William Booth Surabaya.Jl.Cimanuk No.20 Surabaya \\ Email : ethyca.sari@yahoo.com.
}

\begin{abstract}
ABSTRAK
Penyakit degeneratif pada masa tua yang sering muncul salah satunya yaitu hipertensi. Hipertensi merupakan tekanan tinggi didalam pembuluh darah arteri yang mengangkut darah dari jantung dipompa keseluruhan jaringan dan organ tubuh. senam merupakan salah satu hal yang efektif dalam menurunkan tekanan darah, salah satunya senam jantung sehat. Desain penelitian yang digunakan adalah pra eksperimental group pre - post test design, yang bertujuan mengidentifikasi pengaruh senam jantung sehat terhadap tekanan darah pada Lansia. Variabel independen dalam penelitian ini yaitu senam jantung sehat dan variable dependen yaitu tekanan darah pada Lansia. Populasi pada penelitian ini yaitu lansia di Panti Tresna Werdha Hargo Dedali Surabaya berjumlah 16 responden, dengan sampel 16 responden yang dipilih melalui teknik total sampling. Pengukuran tekanan darah menggunakan spygnomanometer. Pengumpulan data dengan checklist. Hasil penelitian menunjukkan sebelum senam jantung sehat tekanan darah 10 orang $(62,5 \%)$ termasuk hipertensi stadium I dan setelah senam jantung sehat didapat tekanan darah 13 orang $(81,25 \%)$ termasuk prehipertensi. Analisa data menggunakan uji statistic Wilcoxon dan diperoleh tingkat signifikan $0,00(p<0,05)$, dengan demikian $\mathrm{H} 0$ ditolak yang berarti ada pengaruh antara senam jantung sehat terhadap tekanan darah pada lansia di Panti Tresna Werdha Hargo Dedali Surabaya. Lanjut usia yang sudah memiliki riwayat hipertensi dianjurkan untuk lebih rutin melaksanakan senam jantung sehat karena dapat membantu lansia menurunkan atau menstabilkan tekanan darah.
\end{abstract}

Kata kunci : Senam Jantung Sehat, Hipertensi, Lanjut Usia.

\begin{abstract}
Degenerative diseases in old age that often appears one of them namely hypertension. Hypertension is high pressure in the arterial blood vessels that carries blood from the heart pumped the whole body tissues and organs. gymnastics is one of the things that are effective in lowering blood pressure, one of them is gymnastics a healthy heart. The research design used was the experimental group pre pre - post test design, aimed at identifying the influence of gymnastics healthy heart against blood pressure in Elderly. Independent variable in research gymnastics is heart healthy and the dependent variable is blood pressure in the elderly. The population in this research is elderly in Parlors Tresna Werdha Hargo Dedali Surabaya totaled 16 respondents, with a sample of 16 respondents are selected via the engineering total sampling. Blood pressure measurement using spygnomanometer. Data collection with checklist. The results showed before gymnastics healthy heart blood pressure 10 people (62,5\%) including hypertension stage I and after gymnastics gained heart-healthy blood pressure 13 people $(81,25 \%)$ including prehipertensi. Data analysis using the Wilcoxon test statistic and acquired a significant level 0,00 ( $p<0,05)$, Thus HO denied which means there is influence between gymnastics healthy heart against blood pressure in elderly in Parlors Tresna Werdha Hargo Dedali Surabaya. Seniors who already have a history of hypertension are advised to implement regular gymnastic more heart healthy because it can help the elderly lower or stabilize blood pressure.
\end{abstract}

Keywords: Gymnastics, hypertension, Seniors. 


\section{PENDAHULUAN}

Menua merupakan proses menghilangnya secara perlahan kemampuan jaringan untuk memperbaiki diri dan mempertahankan struktur dan fungsi normalnya. Usia lanjut atau lanjut usia bukan merupakan suatu penyakit namun suatu tahap lanjut dan proses kehidupan yang ditandai dengan penurunan kemampuan tubuh untuk beradaptasi dengan stress lingkungan (Nugroho, 2009). Masa tua disertai dengan adanya kemunduran kemampuan kerja berbagai sistem didalam tubuh, seperti sistem panca indera, gangguan fungsi didalam tubuh, perubahan psikologi serta adanya penyakit yang muncul. Dengan banyaknya perubahan yang terjadi pada lansia banyak pula masalah kesehatan yang dihadapi. Masalah kesehatan yang dapat muncul pada lansia yaitu munculnya penyakit degeneratif. Penyakit degeneratif yaitu penyakit yang sulit untuk diperbaiki yang ditandai dengan degenerasi organ tubuh yang dipengaruhi gaya hidup. Gaya hidup yang salah saat muda berpengaruh pada kondisi kesehatannya saat tua. Saat seseorang mulai memasuki usia lanjut akan muncul berbagai macam penyakit, seperti diabetes melitus, osteoporosis, osteoarthritis, dan hipertensi. Penyakit-penyakit tersebut merupakan penyakit yang paling sering menyerang seseorang ketika mulai memasuki usia lanjut. Hipertensi merupakan salah satu penyakit yang dapat muncul akibat perubahan gaya hidup yang tidak baik. Hipertensi adalah tekanan tinggi didalam pembuluh darah arteri yang mengangkut darah dari jantung yang memompa ke seluruh jaringan dan organ tubuh. Tekanan darah dibedakan menjadi tekanan darah sistolik dan tekanan darah diastolik. Tekanan darah sistolik adalah tekanan maksimal yang ditimbulkan pada arteri sewaktu darah disemprotkan ke dalam pembuluh, rerata tekanan sistolik adalah 120 mmHg. Tekanan darah diastolik adalah tekanan minimal di dalam arteri ketika darah mengalir keluar menuju ke pembuluh yang lebih kecil dihilir waktu, rerata adalah 80 mmHg. Tekanan darah dikatakan dalam batas normal apabila tekanan darahnya dibawah 120/80 mmHg, sedangkan tekanan darah antara 120/80 $\mathrm{mmHg}$ dan 139/89 $\mathrm{mmHg}$ disebut Pra-Hipertensi dan tekanan darah 140/80 $\mathrm{mmHg}$ dianggap sebagai tekanan darah tinggi atau hipertensi (Muhammadun AS, 2010). Mempertahankan kesehatan pada lansia perlu adanya upayaupaya baik yang bersifat perawatan, pengobatan, pola hidup sehat dan juga upaya lainnya seperti melakukan olahraga yaitu olahraga ringan. Olahraga ringan yaitu olahraga yang mudah dilakukan dan tidak memberatkan yang dapat diterapkan pada lansia. Aktivitas olahraga ini akan membantu tubuh lansia agar tetap bugar dan segar, karena olahraga ini mampu melatih tulang tetap kuat, mendorong jantung bekerja optimal dan membantu menghilangkan radikal bebas yang ada di dalam tubuh. Olahraga yang dapat dilakukan lansia yaitu senam lansia, senam otak, senam kebugaran lansia, senam osteoporosis, jalan santai, dan senam jantung sehat. Dari beberapa senam yang disebutkan diatas, senam jantung sehat merupakan olahraga yang mempunyai tujuan untuk menyehatkan jantung dan senam ini tidak membutuhkan pengeluaran energi yang cukup besar. Olahraga ini berintikan olahraga aerobik dengan irama pelan yaitu olahraga yang banyak menghirup oksigen, dapat memberikan kelenturan, kekuatan, selain itu olahraga memiliki prinsip murah, mudah, meriah, massal, manfaat, dan aman. Olahraga sangat bermanfaat untuk melancarkan peredaran darah dan memperbesar pembuluh darah. Manfaat yang didapatkan oleh lansia saat melakukan senam jantung adalah menghambat proses degeneratif atau proses penuaan. Senam jantung sangat dianjurkan untuk mereka yang memasuki usia pra lansia (45 tahun) dan usia lanjut 65 tahun ke atas 
(Anggriyana Tri Widianti\&Atikah Proverawati, 2010). Berdasarkan penelitian yang dilakukan oleh Rismayanthi (2009) menyatakan bahwa senam dapat menurunkan tekanan darah sistolik dan diastolik. Senam menimbulkan efek beta blocker yang dapat menenangkan sistem saraf simpatikus, dimana bila terjadi penurunan aktivitas simpatik pada pembuluh darah perifer dapat menjadi petunjuk penurunan tekanan darah. Hasil penelitian Rismayanthi (2009) jika melakukan senam dengan intensitas sedang dan lama waktu 20-60 menit serta dilakukan 3 kali sehari dapat menurunkan tekanan darah sistolik dan diastolik pada penderita hipertensi. Sedangkan berdasarkan pengamatan peneliti di Panti Tresna Werdha Hargo Dedali Surabaya saat dilakukan wawancara kepada beberapa perawat yang bertugas di panti tersebut, perawat mengatakan bahwa dulu pernah di lakukan senam untuk menjaga kebugaran lansia, dengan kesibukan perawat dan perawat melanjutkan pendidikan maka kegiatan senam sementara berhenti sehingga membuat beberapa lansia menyatakan kalau badannya terasa sakit, kepala pusing, cepat capek yang menurut mereka karena sudah tidak pernah senam lagi. Hal ini dibuktikan pada saat dilakukan pengukuran tekanan darah ada beberapa lansia mengalami peningkatkan tekanan darah yang selama ini tekanan darah dalam rentang normal menjadi tidak normal. Kebugaran pada lansia seharusnya tetap dijaga supaya penyakit-penyakit degeneratif yang terjadi pada lansia tidak menimbulkan komplikasi yang semakin parah dan lanjut usia semakin bisa menikmati kehidupan yang lebih bahagia serta sehat.

Berdasarkan data dari WHO pada tahun 2009 menunjukkan lansia berjumlah 7,49\% dari total populasi, tahun 2011 menjadi 7,69\% dan pada tahun 2013 didapatkan lansia sebesar $8,1 \%$ dari total populasi (WHO, 2015). Data Riskesdes (2010) juga menyebutkan hipertensi sebagai penyebab kematian nomor tiga setelah stroke dan tuberkulosis, jumlahnya mencapai $6,8 \%$ dari proporsi penyebab kematian pada semua umur di Indonesia (Depkes, 2010). Menurut Riset Kesehatan Dasar tahun 2010, prevelensi hipertensi di Indonesia tahun 2004 sekitar 15\% dengan kisaran 13,4-14,6\% sedangkan pada tahun 2008 meningkat menjadi $16-18 \%$. Berdasarkan data penyakit terbanyak di seluruh rumah sakit Provinsi Jawa Timur 2010 terjadi 4,98\% kasus hipertensi esensial dan $1,08 \%$ kasus hipertensi sekunder. Menurut STP (Surveilans Terpadu Penyakit) Puskesmas di Jawa Timur total penderita hipertensi di Jawa Timur tahun 2011 sebanyak 285.724 pasien. Jumlah tersebut terhitung mulai bulan Januari hingga September 2011. Dengan jumlah penderita tertinggi pada bulan Mei 2011 sebanyak 46.626 pasien (Dinkes Jatim, 2011). Berdasarkan hasil penelitian Rismayanthi (2009), jika melakukan senam dapat menurunkan tekanan darah sistolik sebesar 3,346\% dan diastolik 4,273\%. Berdasarkan hasil study pendahuluan di Panti Tresna Werdha Hargo Dedali Surabaya didapatkan 44 lansia dengan penyakit antara lain Hipertensi sejumlah 16 lansia, 5 lansia menderita DM, 5 lansia menderita Asam Urat, 4 lansia yang menderita Cholesterol, 8 lansia yang menderita Gastritis, 2 lansia yang menderita osteoarthritis, 2 lansia yang menderita glaucoma dan 30 lansia yang menderita demensia.

Menua secara fisiologis ditandai dengan semakin menghilangnya fungsi dari banyak organ tubuh. Hal ini akan menyebabkan semakin cepatnya tubuh kehilangan fungsifungsi, seiring dengan meningkatnya angka harapan hidup dapat kita perkirakan juga akan adanya peningkatan pada prevalensiprevalensi penyakit yang terjadi pada lansia. Salah satu penyakit degeneratif yang terjadi pada lansia adalah hipertensi. Hipertensi adalah penyakit degeneratif pada lansia, yang disebabkan oleh atherosclerosis (penebalan 
dinding arteri yang menyebabkan hilangnya elastisitas pembuluh darah), keturunan, bertambahnya jumlah darah yang dipompa ke jantung. Adapun faktor pencetus hipertensi yaitu daya tahan tubuh terhadap penyakit, genetis, umur, jenis kelamin, adat kebiasaan, pekerjaan, ras atau suku, stress, merokok. Mayoritas penyebab hipertensi belum diketahui dengan pasti yang di sebut hipertensi primer atau essensial. Sedangkan ada juga yang disebabkan oleh kelainan ginjal atau hipertensi renalis dan oleh kelainan hormonal atau hipertensi hormonal. Pengaturan tekanan arteri meliputi kontrol sistem saraf yang kompleks dan hormonal yang saling berhubungan satu sama lain dalam mempengaruhi curah jantung dan tahanan vaskuler perifer. Hal lain yang ikut dalam pengaturan tekanan darah adalah refleks baroreseptor dengan mekanisme di bawah ini. Curah jantung ditentukan oleh volume sekuncup dan frekuensi jantung. Tahanan perifer ditentukan oleh diameter arteriol. Bila diameternya menurun (vasokonstriksi), tahanan perifer meningkat dan bila diameternya meningkat (vasodilatasi) tahanan perifer akan menurun. Pengaturan primer tekanan arteri dipengaruhi oleh baroreseptor pada sinus karotikus dan arkus aorta yang akan menyampaikan impuls ke pusat saraf simpatis di medula oblongata. Impuls tersebut akan menghambat stimulasi sistem saraf simpatis. Bila tekanan arteri meningkat, maka ujung-ujung baroreseptor akan teregang dan memberikan respon terhadap penghambat pusat simpatis, dengan respon terjadinya akselerasi gerak jantung dihambat. Sebaliknya, hal ini akan menstimulasi pusat penghambat penggerak jantung yang bermanifestasi pada penurunan curah jantung. Mekanisme lain terjadinya hipertensi adalah oleh faktor ginjal. Renin yang dilepaskan oleh ginjal ketika aliran darah ke ginjal menurun akan mengakibatkan terbentuknya angiotensin I, yang akan berubah menjadi angiotensin II. Angiotensin
II meningkatkan tekanan darah dengan mengakibatkan kontraksi langsung arteriol sehingga terjadi peningkatan resistensi perifer yang secara tidak langsung juga merangsang pelepasan aldosteron, sehingga terjadi retensi natrium dan air dalam ginjal. Manifesatsi dari ginjal secara keseluruhan akan menyebabkan peningkatan volume darah dan peningkatan darah secara simultan (Arif Mutaqqin, 2012). Dampak apabila hipertensi tidak ditangani adalah terjadi gangguan organ seperti gangguan fungsi jantung koroner, fungsi ginjal, gangguan fungsi kognitif atau stroke. Hipertensi pada dasarnya mengurangi harapan hidup para penderitanya. Penyakit ini menjadi muara beragam penyakit degeneratif yang bisa mengakibatkan kematian. Tekanan darah tinggi yang terus-menerus mengakibatkan kerja jantung ekstra keras, akhirnya kondisi ini berakibat terjadi kerusakan pembuluh darah jantung, ginjal, otak dan mata (Muhammadun A dS, 2010).

Melihat permasalahan tersebut diatas maka salah satu solusi yang bisa dilakukan adalah dengan memberikan pengobatan hipertensi yaitu secara farmakologis dan non farmakologis. Secara farmakologis antara lain obat golongan Diuretik, Angiotensin converting enzyme (ACE) inhibitor, AngiotensiII receptor blocker (ARB), Calcium channel Blocker (CCB), Beta blocker, Alpha blocker, Vasodilator, Centralacting agents. Sedangkan secara non farmakologis antara lain merubah pola makan yang kaya akan kalium dan kalsium yaitu diet yang kaya dengan buah, sayur, dan produk susu rendah lemak dengan kadar total lemak dan lemak jenuh berkurang, diet kaya dengan buah dan sayuran dan rendah lemak jenuh dapat menurunkan tekanan darah pada individu dengan hipertensi, mengurangi asupan garam makanan tinggi garam dan lemak merupakan makanan tradisional pada kebanyakan daerah, tidak jarang pula pasien tidak menyadari kandungan garam pada 
makanan cepat saji, makanan kaleng, daging olahan dan sebagainya, dianjurkan untuk asupan garam tidak melebihi 2.4g (100 $\mathrm{mEq}$ /hari, mengurangi konsumsi alkohol, merokok dan Olah raga (senam).Senam yang dilakukan pada lansia banyak jenisnya salah satunya ialah senam jantung sehat. Senam jantung sehat merupakan olahraga yang disusun dengan mengutamakan kemampuan jantung, gerakan otot besar dan kelenturan sendi serta memasukkan oksigen sebanyak mungkin. Selain meningkatnya perasaan sehat dan kemampuan untuk mengatasi stress keuntungan lain dari senam jantung sehat yang teratur adalah menurunnya tekanan darah, berkurangnya obesitas, berkurangnya frekuensi denyut jantung saat istirahat dan menurunnya resistensi insulin (Sylvia, 2003).Senam jantung sehat terdapat 5 seri, yaitu terdiri dari seri I dimana gerkannya menggunakan irama musik yang pelan dan tidak rumit, seri II gerakan dilakukan sedikit lebih cepat cepat namun masih sederhana, seri III gerakan diiringi dengan musik yang lebih cepat dan gerakan mulai bervariasi, seri IV dan V gerakan diiringi dengan musik yang semakin cepat dan durasi dari gerakan lebih panjang. Pada usia lanjut dapat menggunakan seri I, II dan III. Sedangkan, pada remaja bisa dilakukan seri IV dan V. Frekuensi latihan senam jantung sehat sangat dianjurkan minimal 2 kali dalam seminggu dengan durasi latihan selama 20-30 menit. Peningkatan fisik atau olahraga senam jantung sehat secara teratur dapat menurunkan tekanan darah yang mempengaruhi tekanan darah adalah curah jantung, tekanan pembuluh darah perifer dan volume atau aliran darah. Rata-rata tekanan darah arteri ditentukan oleh curah jantung dan resistensi perifer total. Penurunan tekanan arteri setelah latihan harus dimediasi oleh penurunan satu atau kedua variabel tersebut. Penurunan resistensi perifer total tampaknya menjadi mekanisme utama yang menjadikan penurunan tekanan darah setelah olahraga. Berdasarkan uraian diatas peneliti tertarik untuk mengetahui sejauh mana Pengaruh Senam Jantung Sehat Terhadap Tekanan Darah Pada Lansia di Panti Tresna Werdha Hargo.

\section{Rumusan Masalah}

Berdasarkan latar belakang diatas maka rumusan masalah yang muncul sebagai berikut:

Bagaimana tekanan darah pada lansia sebelum dilakukan senam jantung sehat di Panti Tresna Werdha Hargo Dedali Surabaya?

Bagaimana tekanan darah pada lansia setelah dilakukan senam jantung sehat di Panti Tresna Werdha Hargo Dedali Surabaya?

Bagaimana pengaruh senam jantung sehat terhadap tekanan darah pada lansia di Panti Tresna Werdha Hargo Dedali Surabaya?

\section{Tujuan Penelitian}

\section{Tujuan Umum}

Tujuan umum untuk penelitian ini adalah mengetahui Pengaruh senam jantung sehat terhadap tekanan darah pada lansia di Panti Tresna Werdha Hargo Dedali Surabaya.

Tujuan Khusus

Mengidentifikasi tekanan darah pada lansia sebelum dilakukan senam jantung sehat di Panti Tresna Werdha Hargo Dedali Surabaya

Mengidentifikasi tekanan darah pada lansia setelah dilakukan senam jantung sehat di Panti Tresna Werdha Hargo Dedali Surabaya

Menganalisis pengaruh senam jantung sehat terhadap tekanan darah pada lansia di panti tresna werdha hargo dedali Surabaya 


\section{Manfaat Penelitian}

Bagi Institusi

Hasil penelitian ini diharapkan dapat menjadi tambahan referensi yang bermanfaat bagi mahasiswa STIKES William Booth untuk penelitian selanjutnya

Bagi Panti Werdha

Diharapkan setelah penelitian panti Tresna Werdha Hargo Dedali dapat menerapkan senam jantung sehat guna meningkatkan status kesehatan lansia.

\section{Metode Penelitian}

Rancangan penelitian yang digunakan adalah pra eksperimental group pre - post test design, , yaitu penelitian mengungkapkan hubungan sebab akibat dengan cara melibatkan satu kelompok subjek diobservasi sebelum dilakukan intervensi dan diobservasi lagi setelah dilakukan intervensi (Nursalam, 2011). Populasi dalam penelitian ini adalah Seluruh lansia dengan hipertensi di Panti Tresna Werda Hargo Dedali Surabaya berjumlah 16 lansia dan Sampel Penelitiannya 16 lansia ,teknik sampling dengan menggunakan total sampling .

Analisa data yang digunakan dalam penelitian ini yaitu dengan bantuan aplikasi SPSS mengguanakan uji statistik Wilcoxon. Uji Wilcoxon merupakan salah satu uji statistik untuk mengetahui ada pengaruh senam jantung sehat terhadap tekanan darah pada lansia.Bila nilai $\mathrm{P}<0,05$ berarti $\mathrm{Ho}$ ditolak dikatakan ada pengaruh senam jantung sehat terhadap tekanan darah pada lansia. Jika nilai $\mathrm{P}>0,05$ maka Ho diterima dikatakan tidak ada pengaruh senam jantung sehat terhadap tekanan darah pada lansia.

\section{Hasil Penelitian}

Hasil pengukuran tekanan darah sebelum dilakukan senam jantung sehat. Tabel di bawah ini distribusi data pengukuran tekanan darah sebelum dilakukan senam jantung sehat di Panti Tresna Werdha Hargo Dedali Surabaya .

\begin{tabular}{lccc}
\hline No & $\begin{array}{c}\text { Kategori } \\
\text { Tekanan } \\
\text { Darah }\end{array}$ & Jumlah & $\%$ \\
\hline 1. & Normal & 0 & $0 \%$ \\
2. & $\begin{array}{c}\text { Pre Hipertensi } \\
\text { 3. }\end{array}$ & 0 & $0 \%$ \\
& $\begin{array}{c}\text { Hipertensi } \\
\text { stadium 1 }\end{array}$ & 10 & $62,5 \%$ \\
4. & $\begin{array}{c}\text { Hipertensi } \\
\text { stadium 2 }\end{array}$ & 6 & $37,5 \%$ \\
\hline & Jumlah & 16 & $100 \%$ \\
\hline
\end{tabular}

Berdasarkan tabel diatas didapatkan sebagian besar responden sebelum dilakukan senam jantung sehat memiliki tekanan darah dalam kategori hipertensi stadium 1 sebanyak 10 orang $(62,5 \%)$.

\section{Hasil pengukuran tekanan darah sesudah dilakukan senam jantung sehat.}

Tabel di bawah ini distribusi data pengukuran tekanan darah setelah dilakukan senam jantung sehat di Panti Tresna Werdha Hargo Dedali Surabaya.

\begin{tabular}{llcc}
\hline No & $\begin{array}{l}\text { Kategori } \\
\text { Tekanan } \\
\text { Darah }\end{array}$ & Jumlah & \% \\
\hline 1. & $\begin{array}{l}\text { Normal } \\
(<120 /<80\end{array}$ & 0 & $0 \%$ \\
2. & $\begin{array}{l}\text { mmHg) } \\
\text { Pre Hipertensi } \\
(120-139 / 80-\end{array}$ & 13 & $81,25 \%$ \\
3. & $\begin{array}{l}89 \text { mmHg) } \\
\text { Hipertensi } \\
\text { stadium } \\
(140-159 / 90-\end{array}$ & 3 & $18,75 \%$ \\
4. & $\begin{array}{l}\text { Hipertensi } \\
\text { stadium } \\
(>160 / \geq 100 \\
\text { mmHg) }\end{array}$ & 0 & $0 \%$ \\
\hline \multicolumn{1}{c}{ Jumlah } \\
\hline
\end{tabular}


Berdasarkan tabel diatas didapatkan bahwa seluruh ressponden mengalami penurunan tekanan darah setelah dilakukan senam jantung sehat dan paling banyak responden memiliki tekanan dalam kategori prehipertensi sebanyak 13 orang $(81,25 \%)$.

\section{Distribusi Frekuensi}

Tabel di bawah ini distribusi frekuensi sebelum dan sesudah dilakukan senam jantung sehat di Panti Tresna Werdha Hargo Dedali Surabaya .

\begin{tabular}{|c|c|c|c|c|c|}
\hline \multirow[t]{2}{*}{ No } & \multirow[t]{2}{*}{ Kategori } & \multicolumn{3}{|c|}{$\begin{array}{c}\text { Senam Jantung } \\
\text { Sehat }\end{array}$} & \multirow[t]{2}{*}{$\%$} \\
\hline & & Pre & $\%$ & Post & \\
\hline 1. & $\begin{array}{l}\text { Normal } \\
(<120 /<80 \\
\mathrm{mmHg})\end{array}$ & 0 & $0 \%$ & 0 & $0 \%$ \\
\hline 2. & $\begin{array}{l}\text { Prehipertensi } \\
(120-139 / 80- \\
89 \mathrm{mmHg})\end{array}$ & 0 & $0 \%$ & 13 & $81,25 \%$ \\
\hline 3. & $\begin{array}{l}\text { Hipertensi } \\
\text { stadium } 1 \\
(140-159 / 90- \\
99 \mathrm{mmHg})\end{array}$ & 10 & $62,5 \%$ & 3 & $18,75 \%$ \\
\hline 4. & $\begin{array}{l}\text { Hipertensi } \\
\text { stadium } 2 \\
(\geq 160 / \geq 100 \\
\mathrm{mmHg})\end{array}$ & 6 & $37,5 \%$ & 0 & $0 \%$ \\
\hline & Total & 16 & $100 \%$ & 16 & $100 \%$ \\
\hline
\end{tabular}

Berdasarkan tabel diatas dapat diketahui bahwa sebagian besar responden sebelum dilakukan senam jantung sehat memiliki tekanan darah dalam kategori hipertensi stadium 1 sebanyak 10 orang $(62,5 \%)$ responden yang memiliki tekanan darah dalam kategori hipertensi stadium 2 sebelum dilakukan senam jantung sehat adalah 6 orang $(37,5 \%)$. Sedangkan setelah dilakukan senam jantung sehat didapatkan responden yang mengalami penurunan tekanan darah diantaranya adalah responden yang memiliki tekanan darah dalam kategori prehipertensi adalah 13 orang $(81,25 \%)$, responden dengan tekanan darah dalam kategori hipertensi stadium 1 adalah 3 orang $(18,75 \%)$.
Kemudian data dari sebelum dan sesudah dilakukan senam jantung sehat, tekanan darah responden dianalisa menggunakan uji Wilcoxon melalui komputerisasi dengan derajat kemaknaan $\mathrm{p}<0,05$, didapatkan yaitu signifikasi sebesar $\mathrm{p}=0,00$ maka $\mathrm{H} 1$ diterima, dimana kesimpulannya ada pengaruh senam jantung sehat terhadap tekanan darah pada lansia di panti tresna werdha hargo dedali Surabaya.

\section{Pembahasan}

Pada pembahasan ini akan diuraikan hasil penelitian mengenai "Pengaruh senam jantung sehat terhadap tekanan darah pada lansia di Panti Tresna Werdha Hargo Dedali Surabaya,

\section{Tekanan darah sebelum dilakukan senam jantung sehat}

Berdasarkan dari 16 responden terdapat 10 responden $(62,5 \%)$ memiliki hipertensi stadium I dan 6 responden $(37,5 \%)$ memiliki hipertensi stadium II. Hal ini berarti bahwa seluruh responden di panti Tresna Werdha Hargo Dedali Surabaya sebelum dilakukan intervensi senam jantung sehat telah memiliki tekanan darah tinggi (hipertensi). Menurut Sutanto (2010), Hipertensi merupakan kenaikan tekanan darah di atas normal. Selanjutnya menurut Muttaqin (2012), tekanan darah sistolik lebih dari $120 \mathrm{mmHg}$ dan tekanan diastolik lebih dari $80 \mathrm{mmHg}$. Bila kita lihat data yang diperoleh peneliti dapat diketahui bahwa seluruh responden berusia >60 tahun sebanyak 16 orang (100\%). Menurut Sutanto (2009), hipertensi paling banyak diderita oleh individu yang telah memasuki masa tua (lanjut usia). Selanjutnya menurut Depkes (2009), prevalensi penderita hipertensi pada usia lanjut cukup tinggi sekitar diatas usia 60 tahun. Bila dilihat antara fakta dan teori menunjukan ada kesamaan sebab lanjut usia banyak mengalami perubahan kesehatan yang salah satunya masalah di elastisitas 
pembuluh darah menurun yang berakibat jantung dalam memompa darah harus bekerja sangat keras sehingga mengakibatkan tekanan darah mengalami meningkat, untuk itu pada usia lanjut harus bisa mengontrol tekanan darah secara rutin supaya tidak terjadi komplikasi yang bisa berakibat fatal.

Berdasarkan data diagram responden yang rutin melakukan terapi pengobatan (minum obat antihipertensi) sebanyak 15 orang (94\%). Menurut Muttaqin (2012), penderita hipertensi sering mengkonsumsi obat antihipertensi seperti diuretik, penyakit beta adrenergic, penyekat saluran kalsium, vasodilator dan ACE inhibitor langsung berpengaruh pada tekanan darah. Bila dikaitkan teori dengan fakta diatas ada kesamaan berarti pada pasien yang terkena hipertensi harus mengkomsumsi obat obat golongan hipertensi selamanya sebab pada pasien hipertensi terjadi peningkatan tahanan perifer dikarenakan pada kondisi tersebut tubuh akan kekurangan suplai oksigen sehingga menyebabkan penurunam curah jantung dengan mengkonsumsi obat hipertensi secara rutin akan membantu suplay Oksigen ke seluruh akan lancar sehingga jantung bisa bekerja sesuai dengan fisologis kerja jantung.

Berdasarkan pada diagram dapat diketahui responden memiliki tingkat pendidikan SMP sebanyak 7 orang (44\%). Menurut Sundeen (2002), pendidikan yang rendah akan berpengaruh pada kemampuan berpikir dan menangkap informasi termasuk dalam menguraikan masalah baru. Bila dilihat dari fakta dan teori terdapat keselarasan, dimana pendidikan sangat mempengaruhi kemampuan berpikir seseorang, orang dengan pendidikan tinggi akan lebih cepat mengambil suatu tindakan yang bisa membantu diri sendiri dalan proses pengobatan, sedangkan seseorang yang mempunyai pengetahuan yang kurang maka lebih lambat dalam mengambil keputusan dalam hal pengobatan khsusunya untuk diri sendiri.

\section{Tekanan darah setelah dilakukan senam jantung sehat}

Berdasarkan responden yang
memiliki tekanan darah kategori pre
hipertensi sebanyak 13 orang $(81,25 \%)$,
kategori hipertensi stadium I sebanyak 3
orang $(18,75 \%)$. Hasil tersebut menunjukkan
bahwa telah terjadi penurunan setelah dilakukan senam jantung sehat. Menurut Fakhrudin (2013) mengatakan bahwa Senam jantung sehat termasuk ke dalam olahraga aerobik dengan intensitas sedang.sedangkan menurut Suharjo (2008) menyatakan bahwa Olahraga dapat menurunkan resiko penyakit jantung koroner melalui mekanisme: penurunan denyut jantung dan tekanan darah, penurunan tonus simpatik, meningkatkan diameter arteri koroner dan sistem koleteralisasi pembuluh darah, meningkatkan HDL dan menurunkan LDL darah. Bila dilihat antara fakta dan teori ada kesamaan senam jantung sehat berpengaruh terhadap penurunan tekanan darah sebab setiap gerakan senam yang dilakukan dengan benar dapat memberikan manfaat pada tubuh, menarik tulang punggung dan melatih otot perut serta tubuh lainnya. Sehingga aliran darah menjadi lebih lancar dan mengurangi ketegangan serta menguatkan otot tubuh. Dalam gerakan senam juga terdapat teknik relaksasi pernapasan yang dilakukan. Teknik relaksasi dilakukan oleh responden dapat membantu mengurangi ketegangan dan membuat relaksasi, sehingga jantung tidak memompa darah menjadi terlalu cepat. Keadaan yang tenang dan rileks juga dapat merangsang melepasan hormon endorphin untuk mengatur tekanan darah, selain itu teknik relaksasi pernapasan juga membuat suplai oksigen dalam tubuh lebih besar, sehingga sistem metabolisme pada tubuh juga dapat semakin lancar. 


\section{Pengaruh senam jantung sehat terhadap tekanan darah pada lansia di Panti Tresna Werdha Hargo Dedali Surabaya}

Berdasarkan tabel dapat diketahui bahwa hasil penelitian di Panti Tresna Werdha Hargo Dedali Surabaya responden yang memiliki tekanan darah dalam kategori hipertensi stadium 1 sebanyak 10 orang $(62,5 \%)$ responden yang memiliki tekanan darah dalam kategori hipertensi stadium 2 sebelum dilakukan senam jantung sehat didapatkan responden sebanyak 6 orang $(37,5 \%)$. Pada data hasil penelitian berdasarkan tabel dapat diketahui bahwa hasil penelitian di Panti Tresna Werdha Hargo Dedali Surabaya setelah dilakukan senam jantung sehat didapatkan responden yang mengalami penurunan tekanan darah diantaranya adalah responden yang memiliki tekanan darah dalam kategori prehipertensi adalah 13 orang $(81,25 \%)$, responden dengan tekanan darah dalam kategori hipertensi stadium 1 adalah 3 orang (18,75\%). Kemudian data dari pre dan post tekanan darah responden dianalisa menggunakan uji Wilcoxon melalui komputerisasi dengan derajat kemaknaan $p<0,05$. Sedangkan hasil yang diperoleh yaitu signifikasi sebesar 0,00 maka H1 diterima, dapat disimpulkan bahwa ada pengaruh senam jantung sehat terhadap tekanan darah pada lansia di Panti Tresna Werdha Hargo Dedali Surabaya.

Hasil penelitian ini didukung oleh penelitian yang dilakukan oleh Moniaga (2013) bahwa senam jantung sehat dapat menurunkan tekanan darah sistolik dan diastolik. Dilakukan juga oleh Kellen dan Tran (2001) menyatakan bahwa peningkatan dan penurunan tekanan darah diastolik dipengaruhi oleh lainnya waktu istirahat sebelum dan setelah dilakukan senam serta besar dan lainnya penggunaan oksigen maksimum saat senam dilakukan. Hasil penelitian ini juga sesuai dengan teori Dalimartha (2007) yang menjelaskan bahwa peningkatan kegiatan fisik atau berolahraga secara teratur dapat menurunkan tekanan darah, mengurangi resiko stroke, serangan jantung dan penyakit pembuluh darah lainnya. Begitu juga halnya dengan senam jantung sehat yang dilakukan secara rutin akan menurunkan rata-rata tekanan darah 5$7 \mathrm{mmHg}$ serta pengaruh dari penurunan tekanan darah ini dapat berlangsung sampai 22 jam setelah olahraga. Penurunan tekanan darah sistolik dan diastolik sebanyak 2 $\mathrm{mmHg}$, dapat mengurangi resiko terhadap stroke sampai $14-17 \%$ dan menurunkan resiko terhadap penyakit kardiovaskuler sebesar 9\%. Bila dikaitkan teori dengan fakta diatas ada kesamaan yaitu gerakan senam jantung sehat yang menguatkan dan membentuk otot pada beberapa bagian tubuh dapat meningkatkan daya tahan jantung dan paru-paru.

\section{Simpulan}

Simpulan pada penelitian ini adalah sebagai berikut.

Tekanan darah pada responden lansia sebelum dilakukan senam jantung sehat sebagian besar responden memiliki tekanan darah dalam kategori hipertensi stadium 1 sebanyak 10 orang $(62,5 \%)$.

Tekanan darah pada responden lansia setelah dilakukan senam jantung sehat mengalami penurunan tekanan darah dan responden paling banyak memiliki kategori prehipertensi sebanyak 13 orang $(81,25 \%)$.

Terdapat pengaruh senam jantung sehat terhadap tekanan darah pada lansia di Panti tresna werdha hargo dedali Surabaya dengan bukti hasil signifikasi uji Wilcoxon $\mathrm{p}=0,00$. 


\section{Saran}

\section{Bagi Panti}

Diharapkan bagi Panti Tresna Werdha Hargo Dedali Surabaya $81^{\mathrm{t}}$ dijadikan acuan bagi panti 81 : melaksanakan kegiatan senam jantung sehat secara rutin sehingga dapat meningkatkan kebugaran lansia terutama dalam menurunkan tekanan darah dan mencegah terjadinya komplikasi.

\section{Bagi Institusi}

Diharapkan dengan adanya penelitian ini mahasiswa dapat menambah wawasan baru dan mahasiswa dapat mengaplikasikan dengan pengabdian masyarakat sebagai upaya meningkatkan kesehatan pada lansia.

\section{Bagi Peneliti Selanjutnya}

Diharapkan apabila ada yang ingin melanjutkan penelitian ini dapat menjadi acuan dalam mengembangkan penelitian sehingga pengembangan keilmuan gerontik menjadi lebih baik lagi.

\section{DAFTAR PUSTAKA}

Anggriyana, Tri Widianti dan Atikah Proverawati (2010). Senam Kesehatan

: Dilengkapi dengan contoh gambar. Yogyakarta : Nuh Medika

Arif Muttaqin (2012). Buku Ajar Asuhan Keperawatan Klien Dengan Gangguan Sistem Kardiovaskular dan Hematologi. Jakarta : Salemba Medika Crea,M. (2008). Hypertension. Jakarta : Medya
Darmojo RB, Mariono, HH (2004). Geriatri (Ilmu Kesehatan Usia Lanjut). Edisi 3. Jakarta : Balai Penerbit FKUI

Kosasih, E.N., Setiabudhi, T., dan Heryanto, H. (2005). Peranan anti oksidan pada lanjut usia. Jakarta : Pusat Kajian Nasional Masalah Lanjut Usia. Hal. 5657,65-66.

Lovastatin Kohlmeier (2005) Penyakit Jantung dan Tekanan Darah Tinggi. Jakarta: Prestasi Pustaka Publisher

Muhammadun AS (2010). Hidup Bersama Hipertensi, seringai darah tinggi, Sang Pembunuh Sekejap. Yogyakarta : InBooks

Muttaqin, Arif (2012). Buku Ajar Asuhan Keperawatan Klien Dengan Gangguan Sistem Kardiovaskular Dan Hemtologi. Jakarta : Salemba Medika

Notoatmodjo, Soekidjo (2010). Metodologi Penelitian Kesehatan. Jakarta : Rineka Cipta

Nughroho, Wahjudi. H (20 $\left.\mathrm{C}^{\wedge}\right)$. Komunikasi dalam Keperawatan verontik. Jakarta EGC

Nugroho, Wahjudi H (2008). Keperawatan Gerontik \& Geriatrik,. Edisi 3 Jakarta EGC

Nugroho, Wahjudi H (2000). Keperawatan

Gerontik,. Edisi 2 Jakarta : EGC

Nursalam (2011). Konsep Dan Penerapan Metodologi Penelitian Ilmu Keperawatan. Edisi 3. Jakarta : Salemba Medika

Setyoadi Noerhamdani dan Kushariyadi (2011). Terapi Modalitas Keperawatan Pada Klien. Psikogeriatrik. Jakarta : Salemba Medika 
Stuart and Sundeen, 2002. Buku Saku Keperawatan. Edisi 3. Jakarta : EGC

Potter,P\&Perry,A. (2005). Buku Ajar Fundamental Keperawatan : Konsep,. Proses dan Praktik. Edisi 4. Jakarta : EGC

Rismayanthi, Cerika. 2009. Pengaruh Senam Jantung Sehat Indonesia Terhadap Penurunan Tekanan Darah Penderita Hipertensi. /eprints.uny.ac.id/. diunduh pada tanggal 10 Februari 2018

Shanty, Meita (2011). Silent Killer Deseases.

Yogyakarta : Javalitera

Sylvia A Prise, Lorraine M Wilson. (2003). Patofisiologi Konsep Klinis ProsesProses Penyakit Edisi 6 vol 1 Jakarta : Kedokteran EGC 